Regards sur l'économie allemande

Bulletin économique du CIRAC

$100 \mid 2011$

Varia

\title{
„Affaire“ Sarrazin
}

SCHWARZ P. (ed), Die Sarrazin-Debatte. Eine Provokation - und die Antworten

\section{OpenEdition}

\section{Journals}

Édition électronique

URL : http://journals.openedition.org/rea/4233

DOI : $10.4000 /$ rea. 4233

ISBN : 978-2-8218-0894-2

ISSN : 1965-0787

Éditeur

CIRAC

Édition imprimée

Date de publication : 17 mars 2011

ISSN : 1156-8992

Référence électronique

" „Affaire“ Sarrazin », Regards sur l'économie allemande [En ligne], 100 | mars 2011, mis en ligne le 19 septembre 2011, consulté le 22 septembre 2020. URL : http://journals.openedition.org/rea/4233 DOI : https://doi.org/10.4000/rea.4233

Ce document a été généré automatiquement le 22 septembre 2020

(C) CIRAC 


\section{„Affaire" Sarrazin}

SCHWARZ P. (ed), Die Sarrazin-Debatte. Eine Provokation - und die Antworten

\section{RÉFÉRENCE}

SCHWARZ P. (ed), Die Sarrazin-Debatte. Eine Provokation - und die Antworten, Coll. Große Debatten, Die Zeit, Edel Germany, Hambourg, 2010, 256 p.

1 Ce recueil d'articles parus dans l'hebdomadaire Die Zeit livre un complément précieux au débat de l'été 2009 autour du bestseller de Thilo Sarrazin («Deutschland schafft sich $a b$ "; voir le commentaire publié sur le site du CIRAC). On y relira notamment avec intérêt une tribune libre publiée par Sarrazin en avril 1982, dans laquelle il s'interroge sur les raisons de la crise économique et la montée du chômage. Non, ce n'est pas 'la faute à' l'OPEC ni à l'évolution démographique, écrit-il alors ; mais c'est une résultante d'une profonde mutation des attentes des citoyens à l'encontre de l'Etat providence, liée à un déséquilibre qui s'est installé au fil du temps entre les politiques économique et sociale... (ib) 